\title{
PENGARUH PERTUMBUHAN EKONOMI TERHADAP DISPARITAS PEMBANGUNAN DI PROPINSI SUMATERA SELATAN
}

\author{
Endang Kusdiah Ningsih ${ }^{1}$, Dwi Eka Novianty ${ }^{2}$, Sri Ermeila ${ }^{3}$, \\ ${ }^{1}$ Universitas IBA, Palembang, Indonesia, endanghasan62@gmail.com \\ ${ }^{2}$ Universitas IBA, Palembang, Indonesia, dwiekan@gmail.com \\ ${ }^{3}$ Universitas IBA, Palembang, Indonesia, ermeilasri05@gmail.com
}

\begin{abstract}
Economic growth of any counties had positive and negative impact. A positive impact is an increase in national income and negatif impact are inequility of personal income distribution and development disparities. Economic growth in province of South Sumatera also had that impact. The purposes of this research is to prove empirically relationship and patterns of linkages between economic growth and development disparities. The data that used is secondary data obtained from Central Statistic Agency in the form of economic growth rates, gross regional domestic product per capita and total population of the province of South Sumatera during the period 2010-2017. The analysis use with Williamson Index to measure development disparities and Pearson Correlation to find out the relationship between economic growth and development disparities and to prove Kuznets hypothesis. The result of this analysis are : (1)development disparities in the province of South Sumatera during the period 2010-2017, including height indicated by the Williamson Index more than 0,5. (2) Pearson Correlation is -0,253 show that there is a negatif relationship between economic growth and development disparities and this proved that the Kuznets hypothesis (curve $U$-Reserved) also occur happen in this province. It means, that economic growth is inversely proportional to development disparities.(3) $R$ Square is 0,064, means the effect ofeconomic growth on development disparities is $6 \%$ and $94 \%$ influenced by other factors
\end{abstract}

Keywords : Economic Growth, Development Disparities

\section{PENDAHULUAN}

Pembangunan ekonomi suatu negara mempunyai tujuan akhir untuk meningkatkan kesejahteraan masyarakat. Untuk mencapai tujuan tersebut diperlukan pertumbuhan ekonomi yang tinggi dan pemerataan distribusi pendapatan. Pertumbuhan ekonomi yang tidak diimbangi dengan pemerataan dapat menimbulkan disparitas pembangunan. Disparitas pembangunan ekonomi antar daerah merupakan fenomena universal, disparitas pembangunan merupakan masalah kesenjangan yang serius untuk ditanggulangi baik pada sistem perekonomian pasar maupun ekonomi terencana.(Nurhayani, 2015,h.303)

Menurut Zainuri, (2017,h.2) di Indonesia, ketimpangan antar-wilayah selain warisan historis, juga karena kebijakan pembangunan selama ini lebih menekankan pada pertumbuhan 
ekonomi dan pemerataan pembangunan antar gologan masyarakat serta belum signifikan dalam memfokuskan pemerataan pembangunan antarwilayah. Ketimpangan ini diperkuat pula oleh perbedaan karakteristik wilayah, kuantitas, dan kualitas sumber daya manusia serta kelengkapan infrastrukturnya

Sumatera Selatan adalah salah satu provinsi di Indonesia yang terletak di bagian selatan Pulau Sumatera. Provinsi ini beribukota di Palembang. Secara geografis, Sumatera Selatan berbatasan dengan provinsi Jambi di utara, provinsi Kep. Bangka-Belitung di timur, provinsi Lampung di selatan dan Provinsi Bengkulu di barat.

Sumatera Selatan terdiri dari 13 kabupaten yaitu Ogan Komering Ulu, Ogan Komering Ilir, Muara Enim, Lahat, Musi Rawas, Musi Banyuasin, Banyuasin, OKU Selatan, OKU Timur, Empat Lawang, Pali dan Musi Rawas Utara dan 4 kota yaitu Palembang, Prabumulih, Pagar Alam, Lubuk Linggau.

Berdasarkan harga berlaku, terdapat 2 kabupaten yang memberikan peranan cukup besar terhadap Produk Domestik Regional Bruto (PDRB) yaitu Kabupaten Musi Banyuasin dan Kabupaten Muara Enim dengan peran masing-masing sebesar 14,91\% dan 12,07\%. Akan tetapi bila dilihat dari laju pertumbuhan ekonomi, Kabupaten Musi Banyuasin dan Kabupaten Muara Enim memiliki laju pertumbuhan ekonomi masing-masing sebesar 3,02\% (terendah) dan 8,72\% (tertinggi).

Laju pertumbuhan ekonomi antar kabupaten di provinsi Sumatera Selatan dari tahun 20102017 terlihat pada tabel.1

Tabel 1

Laju Pertumbuhan Ekonomi per Kabupaten

Di Provinsi Sumatera Selatan 2010-2017

\begin{tabular}{|c|l|c|c|c|c|c|c|c|c|}
\hline \multirow{2}{*}{ No } & \multirow{2}{*}{ Kabupaten } & \multicolumn{9}{|c|}{ Tahun } \\
\cline { 2 - 10 } & 2010 & 2011 & 2012 & 2013 & 2014 & 2015 & 2016 & 2017 \\
\hline 1 & $\begin{array}{l}\text { Ogan } \\
\text { Komering } \\
\end{array}$ & 5,10 & 6,17 & 5,26 & 4,34 & 3,57 & 3,05 & 3,95 & 3,93 \\
\hline 2 & $\begin{array}{l}\text { Ogan } \\
\text { Komering Ilir }\end{array}$ & 5,96 & 6,90 & 5,56 & 6,36 & 5,07 & 4,81 & 4,70 & 4,86 \\
\hline 3 & Muara Enim & 5,20 & 5,31 & 8,27 & 8,04 & 3,12 & 7,62 & 5,24 & 8,72 \\
\hline 4 & Lahat & 5,99 & 6,47 & 5,28 & 4,83 & 3,93 & 2,14 & 2,77 & 3,92 \\
\hline 5 & Musi Rawas & 5,16 & 5,89 & 0,85 & 5,88 & 7,44 & 5,13 & 5,41 & 5,21 \\
\hline 6 & $\begin{array}{l}\text { Musi } \\
\text { Banyuasin }\end{array}$ & 3,01 & 3,39 & 7,25 & 3,89 & 4,90 & 2,29 & 2,41 & 3,02 \\
\hline 7 & Banyuasin & 6,10 & 6,14 & 6,15 & 6,18 & 5,14 & 5,56 & 5,88 & 5,08 \\
\hline 8 & OKU Selatan & 6,09 & 6,79 & 5,26 & 5,22 & 5,37 & 4,54 & 5,18 & 4,52 \\
\hline 9 & OKU Timur & 5,87 & 6,58 & 7,20 & 6,96 & 5,19 & 6,05 & 6,15 & 2,67 \\
\hline 10 & Ogan Ilir & 5,58 & 6,68 & 8.03 & 7,43 & 6,67 & 4,43 & 5,12 & 5,13 \\
\hline 11 & Empat & 5,06 & 6,07 & 6,11 & 5,39 & 4,23 & 4,50 & 4,54 & 3,71 \\
\hline
\end{tabular}




\begin{tabular}{|l|l|l|l|l|l|l|l|l|l|}
\hline & Lawang & & & & & & & & \\
\hline 12 & Pali & 3,20 & 2,81 & 7,30 & 5,92 & 0,04 & 4,44 & 5,20 & 5,97 \\
\hline 13 & $\begin{array}{l}\text { Musi Rawas } \\
\text { Utara }\end{array}$ & 4,77 & 5,09 & 2,58 & 2,10 & 9,92 & 3,34 & 3,48 & 4,08 \\
\hline
\end{tabular}

Sumber: Badan Pusat Statistik (data diolah)

Laju pertumbuhan ekonomi suatu daerah dipengaruhi oleh(1) tanah dan kekayaan alamnya, (2) jumlah dan mutu penduduk dan tenaga kerja, (3) barang-barang modal dan tingkat teknologi, (4) sistem sosial dan sikap masyarakat, dan (5) luas pasar sebagai sumber poertumbuhan (Sukirno,2011,h.429). Adanya perbedaan faktor-faktor yang mempengaruhi laju pertumbuhan ekonomi tersebut menjadi salah satu penyebab timbulnya ketimpangan atau kesenjangan pembangunan antar daerah.

Penelitian ini bertujuan untuk melakukan pengujian secara empiris keterkaitan dan hubungan dan pola keterkaitan antara pertumbuhan ekonomi dan ketimpangan pembangunan di Propinsi Sumatera Selatan tahun 2010-2017

\section{Pertumbuhan Ekonomi}

Pembangunan seyogyanya dipandang sebagai proses multidimensi yang mencakup reorganisasi dan reorientasi seluruh sistem ekonomi dan sosial. Selain untuk meningkatkan pendapatan dan keluaran, pembangunan umumnya mengharuskan adanya perubahan radikal dalam struktur lembaga, sosial dan administrasi. Todaro (2011,h.133)

Menurut Tambunan (2012,h.33) bahwa pertumbuhan ekonomi yang tinggi dan berkelanjutan merupakan kondisi utama atau suatu keharusan bagi kelangsungan pembangunan ekonomi dan peningkatan kesejahteraan. Pertumbuhan ekonomi merupakan perkembangan fisikal produksi barang dan jasa yang berlaku di suatu negara (Sukirno, 2011,h.423). Salah satu indikator pertumbuhan ekonomi adalah Produk Domestik Bruto (PDB), untuk tingkat daerah adalah Produk Domestik Regional Bruto (PDRB). Produk Domestik Regional Bruto adalah jumlah nilai tambah bruto (gross value added) yang timbul dari seluruh sektor perekonomian di suatu wilayah/daerah. Tarigan (2004,h.18)

\section{Ketimpangan}

Proses pembangunan yang terjadi pada suatu daerah akan memunculkan fenomena umum yaitu ketimpangan pembangunan antar daerah yang akan membrikan implikasi terhadap proses pembangunan daerah dan tingkat kesejahteraan daerah itu sendiri. Secara umum bentuk implikasi yang ditimbulkan adalah kecemburuan sosial dan ketidakpuasan masyarakat terhadap hasil pembangunan.. 
Ukuran yang digunakan untuk mengetahui ketimpangan pembangunan antar daerah adalah Williamson Index yang digunakan dalam studi Jeffrey G.Williamson pada tahun 1966. Secara ilmu statitik, indeks ini sebenarnya adalah coefficient of varians yang lazim digunakan untuk mengukur suatu perbedaan. Istilah Williamson Index muncul sebagai penghargaan kepada pengguna awal indeks tersebut dalam mengukur ketimpangan pembangunan antar daerah. Walaupun indeks ini mempunyai beberapa kelemahan yaitu antara lain sensitif terhadap definisi dearha yang digunakan dalam perhitungan, namun demikian indeks ini lazim digunakan dalam mengukur ketimpangan pembangunan antar daerah. Sjafrizal (2018,hh.120-121).

\section{METODE PENELITIAN}

\section{Jenis dan Sumber data}

Data yang digunakan dalam penelitiaan ini adalah data sekunder yang mencakup data : (1) data PDRB atas dasar harga berlaku dengan pendekatan pengeluaran, (2) PDRB per kapita , (3)jumlah penduduk. Sumber data adalah Badan Pusat Statitstik (BPS) dan literatur yang berhubungan dengan penelitian.

\section{Jenis Penelitian}

Jenis penelitian ini adalah deskriptif kuantitatif. Pendekatan deskriptif adalah penyajian dan penyusunan data ke dalam bentuk tabel ataupun grafik sedangkan pendekatan kuantitatif yakni data yang diperoleh kemudian dianalisa dengan menggunakan Indeks Williamson dan Korelasi Pearson untuk membuktikan Hipotesa Kutznets tentang U-terbalik.

\section{Metode Analisis}

Indeks Williamson umum digunakan dalam pengukuran ketimpangan pembangunan antar wilayah. Indeks Williamson menggunakan Produk Domestik Regional Bruto (PDRB) perkapita sebagai ketimpangan regional (regional inequality) untuk data dasar (Sjafrizal, 2008). Indeks Williamson bernilai antara $0-1$, dimana semakin mendekati nol artinya pembangunan wilayah tersebut semakin merata. Sedangkan bila mendekati satu maka semakin timpang wilayah.

Untuk mengetahui ketimpangan pembangunan di provinsi Sumatera Selatan dari tahun 2010-2017, digunakan Indeks Williamson, dengan rumus :

$$
V_{w}=\frac{\sqrt{\sum_{i=1}^{n}\left(y_{i}-y\right)^{2}\left(f_{i} / n\right)}}{y}
$$


keterangan : $\mathrm{V}_{\mathrm{w}}=$ Indeks Williamson

$\mathrm{Y}_{\mathrm{i}}=\mathrm{PDRB}$ per kapita masing-masing kabupaten di provinsi Sumatera Selatan

$\mathrm{Y}=\mathrm{PDRB}$ per kapita provinsi Sumatera Selatan

$\mathrm{f}_{\mathrm{i}}=$ Jumlah penduduk masing-masing kabupaten di provinsi Sumatera Selatan

$\mathrm{n}=$ Jumlah penduduk provinsi Sumatera Selatan

Selanjutnya, hipotesa Kuznets menyatakan bahwa pada tahap-tahap awal pertumbuhan ekonomi ketimpangan memburuk atau membesar dan pada tahap-tahap berikutnya ketimpangan menurun, namun pada suatu waktu ketimpangan akan menaik dan demikian seterusnya sehingga terjadi peristiwa yang berulang kali dan jika digambarkan akan membentuk kurva U-terbalik. (Putra,2018,h.250)

Untuk mengetahui hubungan dan pola keterkaitan antara pertumbuhan ekonomi dan ketimpangan pembangunan di provinsi Sumatera Selatan tahun 2010-2017 digunakan korelasi Pearson dan Simple Regresion dengan persamaan :

$$
\mathrm{IW}=\alpha+\beta_{1} \mathrm{Y}+\beta_{2} \mathrm{Y}^{2}+\epsilon
$$

keterangan : $\quad$ IW $=$ Indeks Williamson

$$
\begin{aligned}
& \alpha=\text { kosntansi } \\
& \beta_{1,2}=\text { koefisien regresi } \\
& Y=\text { laju pertumbuhan ekonomi/PDRB per kapita } \\
& \epsilon \quad=\text { Residu }
\end{aligned}
$$

\section{ANALISIS DAN HASIL PEMBAHASAN}

\section{Analisis Indeks Williamson}

Perhitungan ketimpangan pembangunan di provinsi Sumatera Selatan tahun 2010-2017 menggunakan Indeks Williamson, dengan hasil sebagai berikut :

Tabel 2

Nilai Indeks Williamson Provinsi Sumatera Selatan 2010-2017

\begin{tabular}{|c|c|}
\hline Tahun & Indeks Williamson (IW) \\
\hline 2010 & 0,555314488 \\
\hline 2011 & 0.592334436 \\
\hline 2012 & 0.585143429 \\
\hline 2013 & 0,589254944 \\
\hline 2014 & 0,905968803 \\
\hline 2015 & 0,560172710 \\
\hline 2016 & 0,536434933 \\
\hline 2017 & 0,528480709 \\
\hline
\end{tabular}

Sumber : data diolah(2019) 
Berdasarkan tabel 2diatas, terlihat bahwa ketimpangan pembangunan di propinsi Sumatera Selatan dari tahun 2010 - 2017 dan 2015-2017 masuk dalam kategori tinggi karena nilai IW >0,35. Sedangkan pada tahun 2014, ketimpangan pembangunan yang terjadi sangat tinggi karena nilai IW mendekati 1, yaitu sebesar 0.90

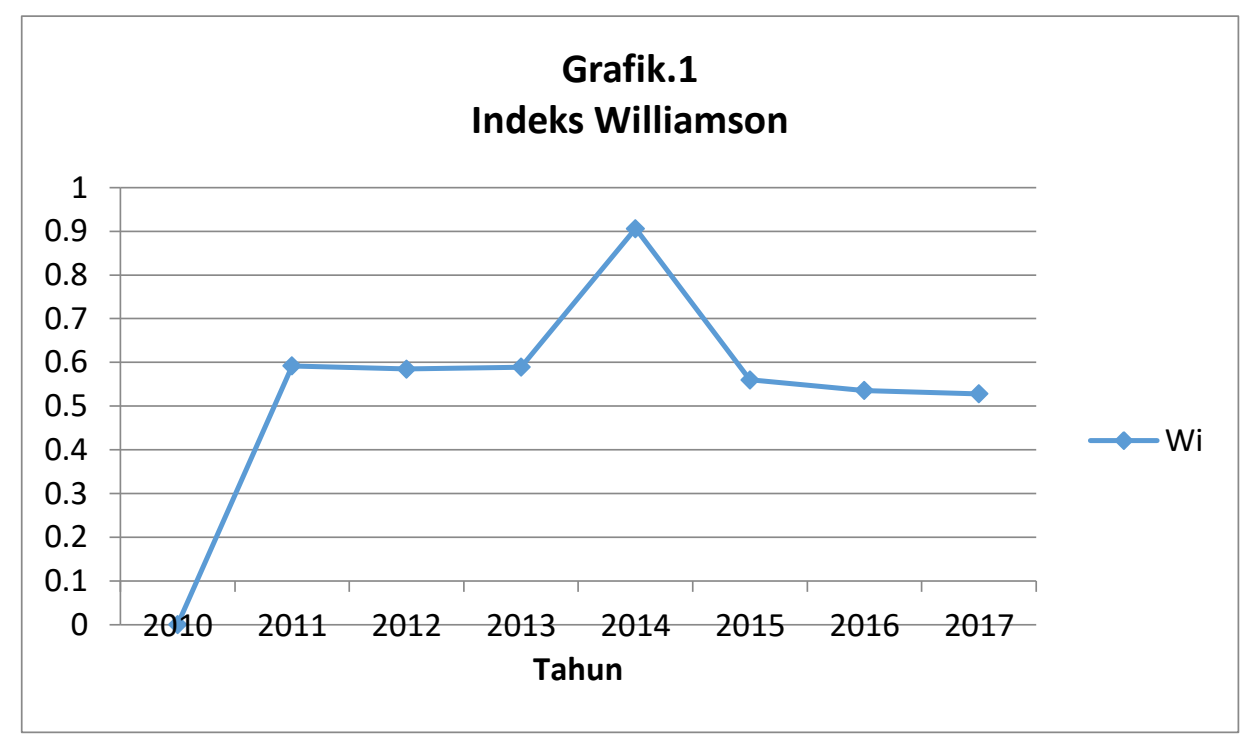

Tingginya tingkat ketimpangan di propinsi Sumatera Selatan, sejalan dengan hasil penelitain Andhiani dkk, (2018,h.30) bahwa angka Indeks Williamson yang berada diatas 0,5 ( IW $>0,5)$ atau golongan ketimpangan tinggi yaitu berada di Provinsi Sumatera Utara, Provinsi Jambi, Provinsi Sumatera Selatan, dan Provinsi Kepulauan Riau untuk tahun 2011-2015.

Selanjutnya hasil penelitian yang telah dilakukan oleh Yeniwati, (2013,h.9) juga membuktikan bahwa dari 10 propinsi yang terdapat di Sumatera terdapat 5 propinsi yang memiliki indeks ketimpangan diatas rata-rata yaitu propinsi Nangro Aceh Darussalam, Sumatera Utara, Riau, Sumatera Selatan dan propinsi Kepulauan Riau, sementara 5 propinsi lagi memiliki indeks ketimpangan di bawah rata-rata.yaitu propinsi Sumatera Barat, Jambi, Bengkulu, Lampung dan Propinsi Bangka Belitung.

Menurut Umiyati (2013,h.42) pertumbuhan ekonomi di wilayah Sumatera mempunyai tingkat keragaman yang berbeda-beda, hal ini dikarenakan setiap Propinsi memiliki perbedaan potensi baik dari sumber daya alam maupun sumberdaya manusia dan kualitas teknologi yang dimiliki oleh Propinsi tersebut.

Sjafrizal (2018, h.136-138 ), menjelaskan penyebab umum terjadinya ketimpangan ekonomi antar daerah adalah :

1. Perbedaan kandungan sumber daya alam

2. Perbedaan kondisi demografis 
3. Kurang lancarnya mobilitas barang dan jasa

4. Konsentrasi kegiatan ekonomi daerah

5. Alokasi Dana Pembangunan antar daerah

\section{Analisis Korelasi Pearson}

Untuk mengetahui hubungan antara pertumbuhan ekonomi dan ketimpangan pembangunan di propinsi Sumatera Selatan digunakan analisis korelasi Pearson berdasarkan data pada tabel 3.

Tabel 3.

Indeks Williamson dan Pertumbuhan Ekonomi

Propinsi Sumatera Selatan 2010-2017

\begin{tabular}{|c|c|c|}
\hline Tahun & Indeks Williamson (IW) & Laju Pertumbuhan Ekonomi \\
\hline 2010 & 0,555314488 & 5,63 \\
\hline 2011 & 0.592334436 & 6,36 \\
\hline 2012 & 0.585143429 & 6,83 \\
\hline 2013 & 0,589254944 & 5,31 \\
\hline 2014 & 0,905968803 & 4,79 \\
\hline 2015 & 0,560172710 & 4,42 \\
\hline 2016 & 0,536434933 & 5,03 \\
\hline 2017 & 0,528480709 & 5,51 \\
\hline
\end{tabular}

Sumber : data diolah (2019)

Hasil perhitungan menggunakan korelasi Pearson, menunjukkan bahwa terdapat hubungan yang negatif antara pertumbuhan ekonomi dan ketimpangan pembangunan sebesar -0,253 dengan nilai signifikansi sebesar 0,545 > 0,05. Dengan kata lain, peningkatan pertumbuhan ekonomi akan menyebabkan penurunan ketimpangan dalam pembangunan. Hasil ini juga membuktikan bahwah hipotesa Kuznets tentang kurva U-terbalik berlaku di propinsi Sumatera Selatan pada tahun 20102017.

Hipotesa Kuznets tentang U-terbalik ini juga berlaku di propinsi Jawa Timur pada periode tahun 2005-2011, berdasarkan hasil penelitian yang dilakukan oleh Nurhuda dkk (2013,h.114), Penelitian yang dilakukan oleh Maria (2018,h.253) juga membuktikan bahwa hubungan antara Indeks Williamson dengan PDRB per kapita yang bersifat nonlinier. Hubungan tersebut ditunjukkan dalam bentuk kurva huruf $U$ terbalik, yang artinya bahwa Hipotesis Kuznets berlaku di Pulau Kalimantan pada periode pengamatan.

Hasil yang berbeda diperoleh dari penelitian yang dilakukan oleh Berlianantya (2017,h.169) dimana hubungan antara pertumbuhan ekonomi dan ketimpangan pembangunan Provinsi Jawa Timur selama tahun 2004-2013 mempunyai hubungan yang tidak signifikan, sehingga tidak dapat menjelaskan hubungan pertumbuhan ekonomi dan ketimpangan pembangunan. Hipotesis Kuznets tentang $U$ terbalik tidak terbukti selama periode pengamatan karena pola hubungan antara pertumbuhan ekonomi dan ketimpangan pembangunan cenderung berbentuk $U$. 


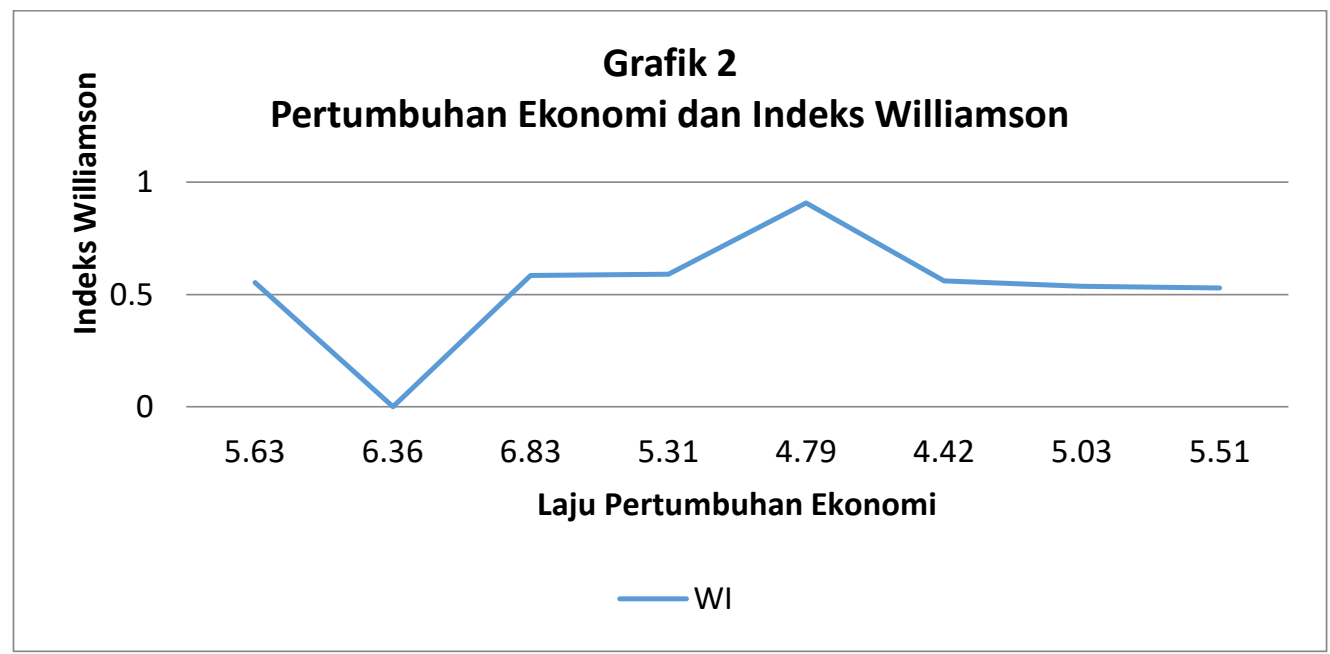

\section{KESIMPULAN DAN SARAN}

Berdasarkan hasil perhitungan yang dilakukan, maka diambil kesimpulan sebagai berikut :

Hasil perhitungan Indeks Williamson menujukkan bahwa tingkat ketimpangan pembangunan di propinsi Sumatera Selatan dalam rentang waktu 2011-2017 termasuk kategori tinggi bahkan pada tahun 2014 masuk kategori sangat tinggi.

Hasil analisis korelasi Pearson menujukkan bahwa terdapat hubungan yang negatif antara pertumbuhan ekonomi dan ketimpangan pembangunan artinya peningkatan pertumbuhan ekonomi akan menyebabkan penurunan ketimpangan dalam pembangunan.

Untuk meminimalkan dampak pembangunan ekonomi terhadap ketimpangan pembangunan maka perlu adanya program pemerataan pembangunan yang berkeadilan di semua bidang.

\section{REFERENSI}

Andhiani,D.K.,Erfit.,\& Bhakti,A. (2018). Analisis Pertumbuhan Ekonomi dan Ketimpangan Pembangunan di Wilayah Sumatera. e-Jurnal Perspektif Ekonomi dan Pembangunan Daerah, 7(1), 26-34.

Badan Pusat Statistik, (2018). Provinsi Sumatera Selatan Dalam Angka. Palembang. Badan Pusat Statistik Provinsi Sumatera Selatan.

Berlianantia,M. (2017). Pertumbuhan Ekonomi Dan Ketimpangan Pembangunan Ekonomi Antar Wilayah Kebijakan Pembangunan Di Provinsi Jawa Timur. Equilibrium,5(2),163-171.

Maria,C.Y.P. (2018). Disparitas \& Transformasi Struktural Antar Kabupaten/Kota di Kalimantan. Inovasi Pembangunan-Jurnal Kelitbangan,6(3),239-260.

Nurhayani.,Hodihaj,S.,Bhakti,A.(2015). Analisis Disparitas Pembangunan Ekonomi Dan Hubungannya Dengan Investasi Di Provinsi Jambi Tahun 2002-2014. Jurnal Paradigma Ekonomika,10(2),302-311.

Nurhuda, R.,Muluk,K.M.R.,\&Prasetyo,Y.M. Analisis Ketimpangan Pembangunan (Studi di Provinsi Jawa Timur Tahun 2005-2011). Jurnal Administrasi Publik (JAP), 1(4), 110-119.

Putra, W. (2018). Perekonomian Indonesia: Penerapan Beberapa Teori Ekonomi Pembangunan di Indonesia. Depok. PT Raja Grafindo Persada. 
Sjarizal.(2018). Analisis Ekonomi Regional Dan Penerapannya D Indonesia. Depok. PT Raja Grafindo Persada

Sukirno, S. (2011). Makroekonomi Teori Pengantar (Edisi 3). Depok. PT Raja Grafindo Persada.

Tambunan, T.H. (2011). Perekonomian Indonesia Kajian Teoritis Dan Analisis Empiris. Bogor. Penerbit Ghalia Indonesia

Tarigan,R.(2004). Ekonomi Regional Teori dan Aplikasi. Jakarta. PT Bumi Aksara

Todaro,M.P.,Smith.S,C. 2011. Ekonomi Pembangunan (Edisi 11), Jilid 1. Jakarta .Penerbit Erlangg Umiyati,E.(2013). Analisa Pertumbuhan Ekonomi Dan Ketimpangan Pembangunan Antar Wilayah Di Pulau Sumatera. Jurnal Paradigma Ekonomika, 1(7),42-50.

Yeniwati. (2013). Ketimpangan Ekonomi Antar Provinsi di Sumatera. Jurnal Kajian Ekonomi,II(03), 1-21.

Zainuri,A., Jamal,A. (2017). Disparitas Pembangunan Ekonomi di Indonesia. Jurnal Ilmiah Mahasiswa (JIM) Ekonomi Pembangunan Fakultas Ekonomi dan Bisnis Unsyiah, 2(1),1-10. 